\title{
Toward the satellite monitoring of glacier changes on Mount Kenya
}

\author{
Stefan Hastenrath \\ Department of Meteorology, University of Wisconsin-Madison, 1225 West Dayton Street, Madison, WI 53706, U.S.A.
}

\begin{abstract}
For a pilot study of change detection of small tropical mountain glaciers from SPOT satellite, Mount Kenya was chosen because a map at scale $1: 5000$ in a local coordinate system, based on aerial photography in September 1987, provided a control for mapping of horizontal ice extent, and because the precipitous relief offered a particular challenge for technique development. A terrain model in compatible map projection was constructed from the topography of the 1987 map. A SPOT subscene of February 1988 was geocoded and terrain corrected to conform with the terrain model and identifiable terrain features. Another 26 control points established on the ground were entered in the digital array. The pixels were re-sampled to a nominal resolution of $10 \mathrm{~m}$. This digital map was output at scale 1:5000. The glacier boundaries and the location of the terrain control points agreed with the September 1987 map within the mapping accuracy commensurate with the 1:5000 scale. This satellite-based mapping provides an internally consistent reference for determining the changes of Mount Kenya's glaciers from February 1988 to a SPOT sampling intended for the mid-1990s. This pilot study further indicates the feasibility of glacier change detection on various other high mountains of the tropics.
\end{abstract}

\section{INTRODUCTION}

In the context of global climatic change, the variations of tropical mountain glaciers merit particular attention. The glacierized mountain regions of the tropics are not easily accessible and systematic mappings from terrestrial or airborne photogrammetry have been rare. Monitoring from satellite appears an obvious option, but the spatial resolution of LANDSAT was far too coarse to assess changes in the small tropical glaciers. The considerably finer resolution of SPOT opens the prospect for applications to glacier change detection in the tropics. With this motivation Mount Kenya was chosen for a pilot study, because our extensive earlier work (Hastenrath, 1984; Hastenrath and others, 1989; Hastenrath and Kruss, 1992a, b) has examined the sensitivity of its glaciers to climatic variations and has created an unusual topographic basis, and because the extreme local relief posed particular challenges to technique development. The present paper reports the results of a satellite-based digital mapping of Mount Kenya's glaciers, and discusses the potential of this approach for the small glaciers on Mount Kenya and other high mountains of the tropics.

\section{BACKGROUND}

Mount Kenya has been an object of our research on tropical glacier and climate variations over two decades (Hastenrath, 1984). Field work since the mid 1980s included the gradual establishment of a network of ground-control points all around the glacierized peak region. This used electromagnetic distance measuring equipment (EDM) and optical theodolite (Hastenrath and others, 1989) and linked up with topographic control points created by the IGY Mount Kenya Expedition in 1957-58 (Charnley, 1959). We marked the control points in the terrain with white paint in preparation for aerial photography flown on 3 September 1987. Of the total of 26 ground control points 14 were used for aerial triangulation and stereo-plotting. A map was produced at scale 1:5000 (Hastenrath and others, 1989; World Glacier Monitoring Service, 1992), conforming in scale and area with an earlier map based on terrestrial photogrammetry in January 1963 (Forschungsunternehmen Nepal-Himalaya, 1967). Both maps used a local coordinate system stemming from the IGY Mount Kenya Expedition. A simplified version of our 1987 map reduced to scale 1:15000 is shown in Figure 1. A central frame from the 3 September 1987 aerial survey is reproduced in Figure 2 at approximately the same scale. Noteworthy with regard to Figures 1 and 2 is the extreme local relief of about $1 \mathrm{~km}$ within a $2 \times 2 \mathrm{~km}$ horizontal area.

From a comparison of the 1963 and 1987 maps it was possible to determine quantitatively not only the area decrease but also the thickness changes of the glaciers on Mount Kenya over the past quarter century (Hastenrath and others, 1989). The ice thinning amounted to about $15 \mathrm{~m}$ for all glaciers, regardless of topographic location and thus exposure to solar radiation. The ice thickness change, in turn, was evaluated in terms of the glacier heat budget, and on these grounds we estimated the sensitivity 


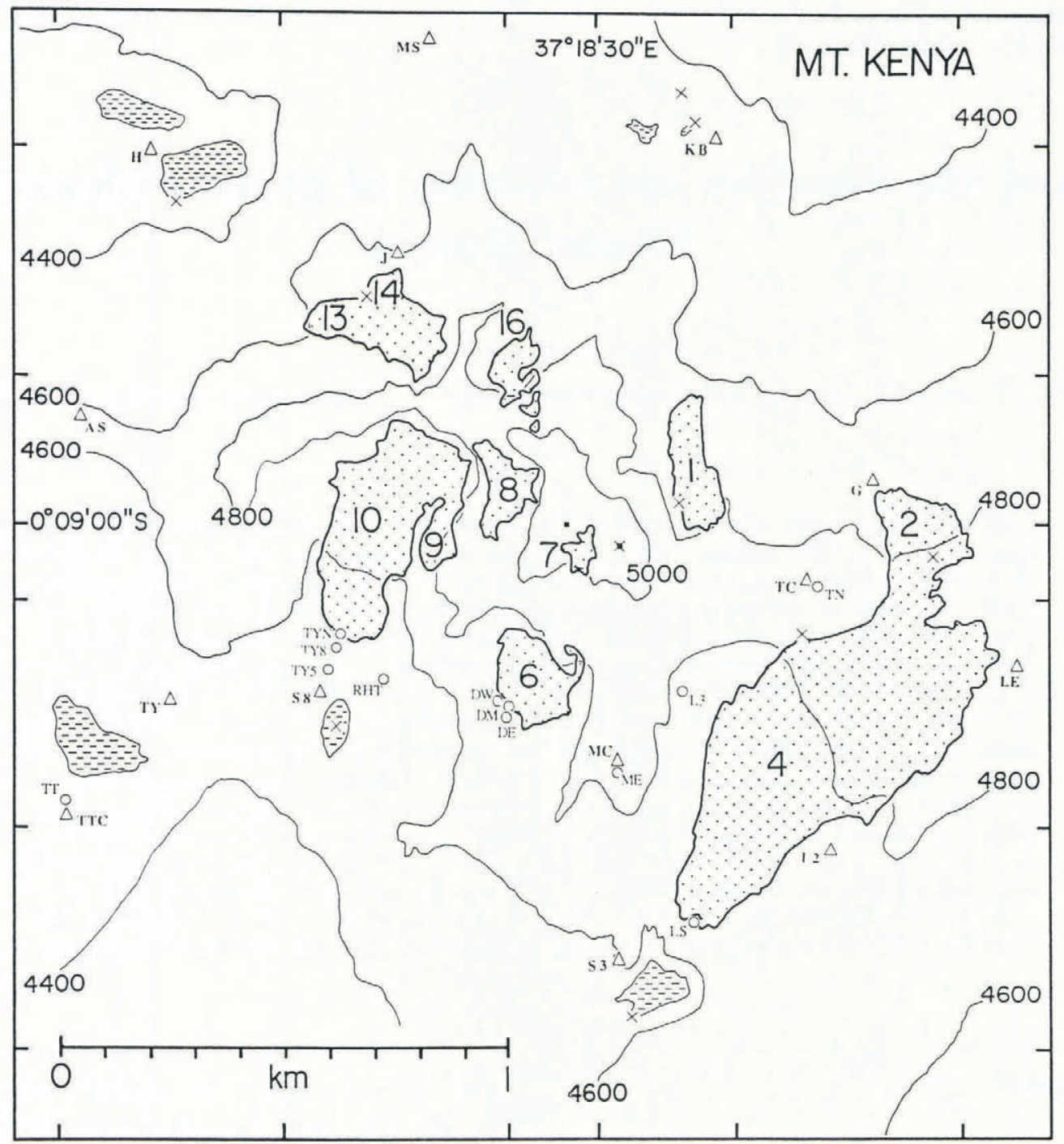

Fig. 1. Map of Mount Kenya's glaciers on 3 September 1987. The key below lists for the north and south sides of the mountain and from west to east the names of the glaciers indicated in the map by number. Triangles indicate terrain control points used in the 1987 mapping, and open circles other control points surveyed and marked in the terrain, with letter code referring to Hastenrath and others (1989). Crosses represent terrain features identified for geocoding of digital SPOT scene. Square dots mark the highest peaks (Batian $5199 \mathrm{~m}$, and Nelion $5188 \mathrm{~m}$ ). Height contours are at $200 \mathrm{~m}$ spacing and scale is 1:15000 (source: Hastenrath and others, 1989). Dot raster denotes glaciers and dash raster lakes. North side: 13 Cesar, 14 Joseph, 16 Northey, 1 Krapf, 2 Gregory; south side: 10 Tyndall, 9 Heim, 8 Forel, 7 Diamond, 6 Darwin, 4 Lewis.

of the glaciers to changes of the atmospheric environment that may be steered by the greenhouse effect through various lines of causality (Hastenrath and Kruss, 1992a, b). In particular, we concluded that a slight increase of astmospheric humidity - itself largely controlled by conditions over the Indian Ocean - was instrumental in reducing sublimation and thus making energy available for enhanced melting.

With such climatic objectives, remote sensing by satellite is of interest for determining area and area changes, if not elevations and thickness changes. The potential and limitations of LANDSAT imagery have been explored by Allison and Peterson (1989) for New Guinea and by Young and Hastenrath (1991) for East
Africa. The $80 \mathrm{~m}$ resolution of LANDSAT was found not suitable for area change detection of the small tropical glaciers.

\section{EVALUATION OF SPOT SCENE}

The pixel size of SPOT is $20 \mathrm{~m}$ for multi-channel, and $10 \mathrm{~m}$ for panchromatic scenes. Resampling allows sharpening to nominal resolutions of 10 and $5 \mathrm{~m}$, respectively. These values should be seen in perspective with the 1963-87 terminus retreats of Mount Kenya's glaciers of mostly between 50 and $150 \mathrm{~m}$, and the scale of our $1987 \mathrm{map}$ ( $1 \mathrm{~mm}$ on the map corresponding to $5 \mathrm{~m}$ in 


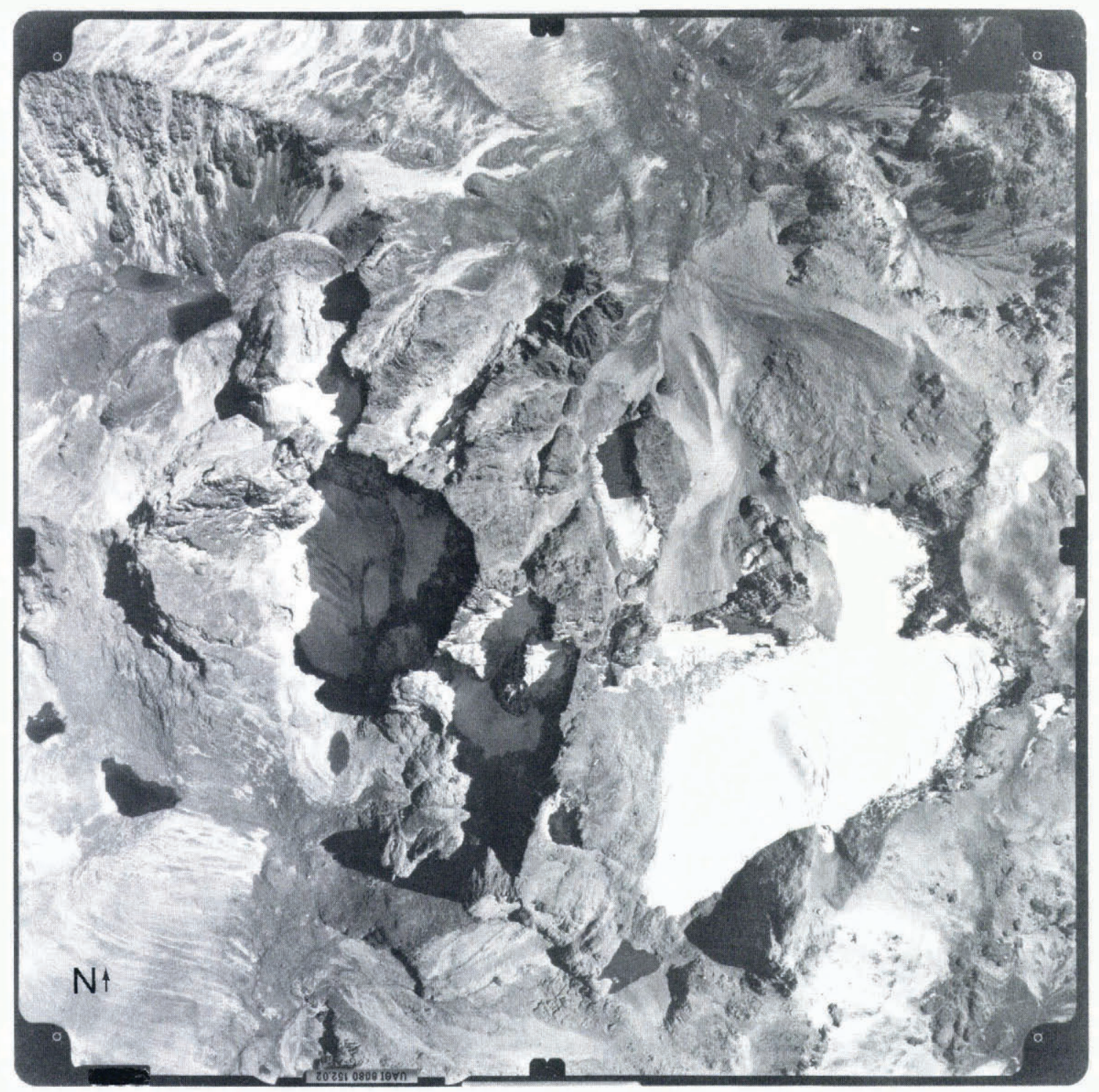

Fig. 2. Air photograph of Mount Kenya's glaciers on 3 September 1987, of flight (PHOTOMAP Kenya Ltd.) from which map was produced by aerial photogrammetry (Hastenrath and others, 1989). Approximate scale 1:15000.

the terrain). From these magnitude considerations it was found desirable to map the ice extent on Mount Kenya in scale and coordinate system consistent with our map based on aerial photogrammetry (Hastenrath and others, 1989), from a SPOT pass as close as possible to the 3 September 1987 date of our map. From a search of the SPOT files, a cloudless panchromatic shot of 3 March 1987 appeared most desirable, but this was found damaged in the SPOT archives. The second choice then was a cloudless multi-channel subscene of 4 February 1988 , and this proved to be of good quality.

In preparation for the processing of the SPOT subscene, a digital terrain model at $5 \mathrm{~m}$ cell size was constructed from the topography in our September 1987 map (Hastenrath and others, 1989), and a compatible map projection was created (polyconic projection, Clarke 1880 Ellipsoid, consistent with ARC 1960 datum used in Kenya; central meridian $37^{\circ} 18^{\prime} 30^{\prime \prime} \mathrm{E}$, latitude origin $0^{\circ} 09^{\prime} 00^{\prime \prime} \mathrm{S}$, false easting 2700.00 , false northing 2165.00). Prominent terrain features were then identified on the September 1987 map (Fig. 1) and in the February 1988 satellite image. On this basis, the digital subscene was geocoded and terrain corrected, using the procedure described by Marvin and others (1987), to conform with the terrain model and identifiable terrain features. The 26 control points established on the mountain from a precision ground survey (see above), but not visible on SPOT, were entered in the digital array. The pixels were resampled to a nominal resolution of $10 \mathrm{~m}$.

\section{RESULTS AND OUTLOOK}

The digital map with date 4 February 1988 created as described above was produced in the form of a photo-map at scale 1:5000, so as to be compared against our 3 September 1987 map constructed from aerial photogrammetry (Hastenrath and others, 1989). A digital computer print at scale 1:15000 is reproduced in Figure 3 for comparison with Figures 1 and 2. The glacier 
boundaries and the location of the terrain control points on the SPOT photo-map (4 February 1988) and on the air-photogrammetric map (3 September 1988) agreed within the mapping accuracy commensurate with the 1:5000 scale. Various digital enhancements were found possible on the screen of a Macintosh computer. These may bring out the fine structure of crevasse patterns and moraine systems. A distinctly seasonal feature is apparent on the 4 February 1988 SPOT subscene (Fig. 3), namely the brightness of the glaciers on the north side of the mountain, at variance with the 3 September 1987 air photograph (Fig. 2), but consistent with the experience that the glaciers in those quadrants are snow-covered in boreal winter but become bare in summer.

This effort of mapping the glaciers of Mount Kenya from satellite faced as major difficulties the extreme local relief, the reference to a local rather than absolute coordinate system, and the demanded fine scale of
$1: 5000$. The results are encouraging. Given the prospect of an intensifying greenhouse effect, tropical glaciers may continue to retreat at an accelerated rate (Hastenrath and Kruss, 1992a, b). The work completed will provide an internally consistent reference for determining the changes of Mount Kenya's glaciers from February 1988 to a SPOT sampling intended for the mid-1990s, which may further be complemented by a remapping from purpose-flown aerial photography. The present pilot study for Mount Kenya also indicates the feasibility of detecting, with adequate accuracy, changes of the relatively small glaciers on other tropical mountains.

\section{ACKNOWLEDGEMENTS}

This study was supported by U.S. National Science Foundation Grants EAR-9016657 and EAR-9217211.

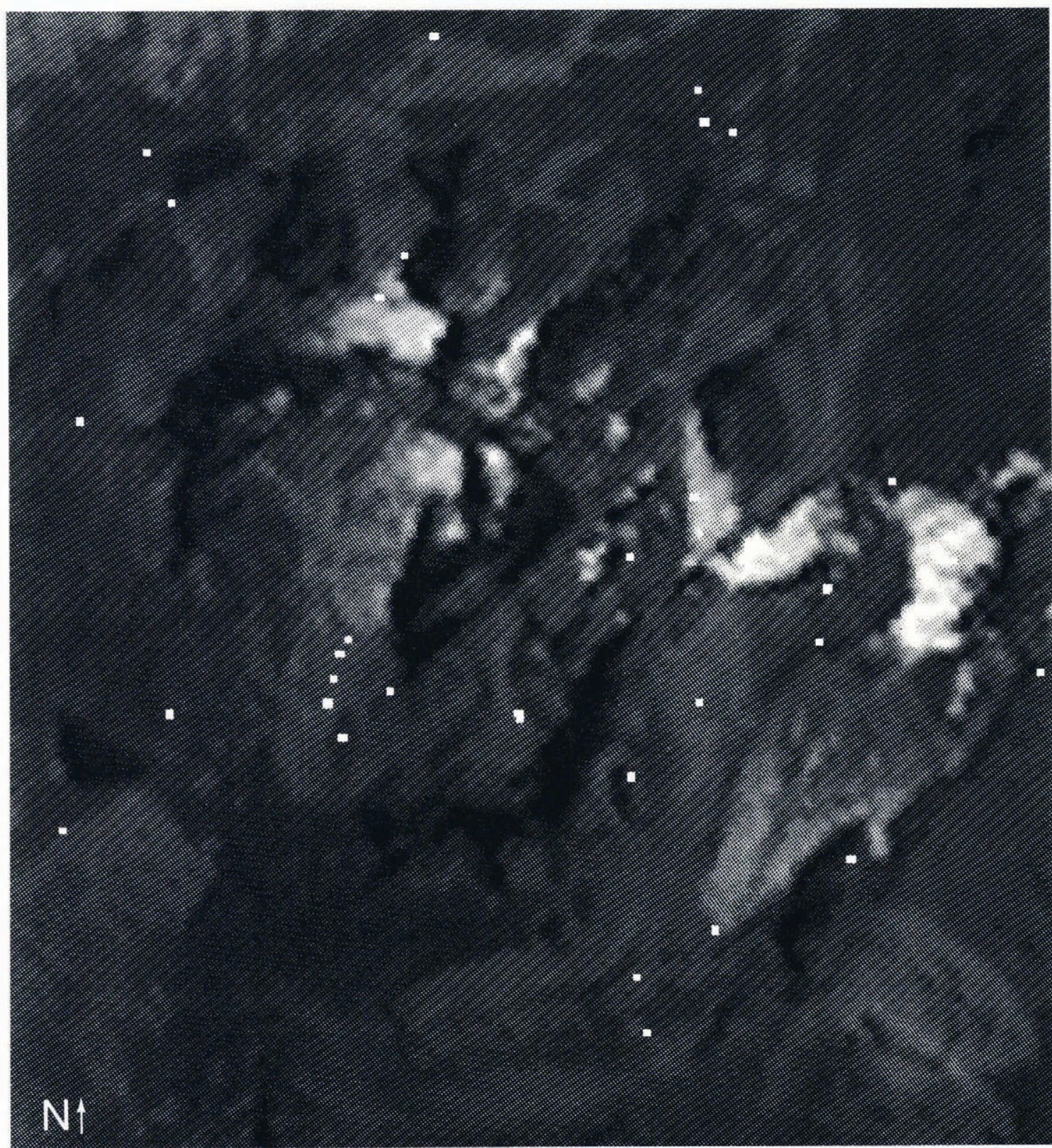

Fig. 3. Digital map of Mount Kenya's glaciers produced from multi-channel SPOT subscene of 4 February 1988. Points identified in the map Figure 1 are shown by small dots. Scale is $1: 15000$. 
Processing of the digital satellite information was performed at STX Remote Sensing Services, Lanham, MD. The glacier research is authorized by the Office of the President, Republic of Kenya.

\section{REFERENCES}

Allison, I. and J. A. Peterson. 1989. Glaciers of Irian Jaya, Indonesia. U.S. Geol. Surv. Prof. Pap. 1386H, 11-20.

Charnley, F. E. 1959. Some observations on the glaciers of Mt. Kenya. 7. Glaciol., 3(26), 483-492.

Forschungsunternehmen Nepal-Himalaya. 1967. Mount Kenya 1:5000. Wien, Kartographische Anstalt FreytagBerndt und Artaria.

Hastenrath, S. 1984. The glaciers of equatorial East Africa. Dordrecht, etc., D. Reidel Publishing Co.

Hastenrath, S. and P.D. Kruss. 1992a. Greenhouse indicators in Kenya. Nature, 355(6360), 503-504.
Hastenrath, S. and P.D. Kruss. 1992b. The dramatic retreat of Mount Kenya's glaciers between 1963 and 1987: greenhouse forcing. Ann. Glaciol., 16, 127-133.

Hastenrath, S., R. Rostom and R. A. Caukwell. 1989. Variations of Mount Kenya's glaciers, 1963-87. Erdkunde, 43(3), 202-210.

Marvin, J.W., M.L. Labovitz and R. Wolfe. 1987. Derivation of a fast algorithm to account for distortions due to terrain in earth-viewing satellite sensor images. IEEE Trans. Geosci. Remote Sensing, GE-25(2), 244-251.

World Glacier Monitoring Service. In press. Fluctuations of glaciers 1986-90 (Vol. VI). Zürich, IAHS-UNEPUNESCO.

Young, J.A.T. and S. Hastenrath. 1991. Glaciers of Africa. U.S. Geol. Surv. Prof. Pap. 1386G, 49-70.

The accuracy of references in the text and in this list is the responsibility of the author, to whom queries should be addressed. 